University of Nebraska - Lincoln

DigitalCommons@University of Nebraska - Lincoln

2001

\title{
Source Identification of Nitrate on Cheju Island, South Korea
}

Roy F. Spalding

University of Nebraska - Lincoln, rspalding1@unl.edu

Z. K. U

Cheju National University

S. W. Hyun

South Korea Agricultural Research and Extension Service,

G. E. Martin

University of Nebraska-Lincoln

Mark E. Burbach

University of Nebraska-Lincoln, mburbach1@unl.edu

See next page for additional authors

Follow this and additional works at: https://digitalcommons.unl.edu/natrespapers

Spalding, Roy F.; U, Z. K.; Hyun, S. W.; Martin, G. E.; Burbach, Mark E.; Yang, S. I. I.; Kim, M.; Exner Spalding, Mary; and Song, S. J., "Source Identification of Nitrate on Cheju Island, South Korea" (2001). Papers in Natural Resources. 371.

https://digitalcommons.unl.edu/natrespapers/371

This Article is brought to you for free and open access by the Natural Resources, School of at DigitalCommons@University of Nebraska - Lincoln. It has been accepted for inclusion in Papers in Natural Resources by an authorized administrator of DigitalCommons@University of Nebraska - Lincoln. 


\section{Authors}

Roy F. Spalding, Z. K. U, S. W. Hyun, G. E. Martin, Mark E. Burbach, S. I. I. Yang, M. Kim, Mary Exner Spalding, and S. J. Song 


\title{
Source Identification of Nitrate on Cheju Island, South Korea
}

\author{
R. F. Spalding, ${ }^{1}$ Z. K. U, ${ }^{2}$ S. W. Hyun, ${ }^{3}$ G. E. Martin, ${ }^{1}$ M. E. Burbach, ${ }^{4}$ \\ S.I.I. Yang, ${ }^{3}$ M. Kim, ${ }^{5}$ M. E. Exner, ${ }^{6}$ and S. J. Song ${ }^{3}$
}

1. Department of Agronomy and Horticulture, University of Nebraska-Lincoln, Lincoln, NE 68583-0915, USA

2. Applied Radioisotope Research Institute, Cheju National University, 690 756, Cheju-Shi, Cheju-do, Rep. of Korea

3. South Korea Agricultural Research and Extension Service, 690 170, Cheju-Shi, Cheju-do, Rep. of Korea

4. Water Sciences Laboratory, University of Nebraska-Lincoln, Lincoln, NE 68583-0844, USA

5. Department of Biometry, University of Nebraska-Lincoln, Lincoln, NE 68583-0712, USA

6. School of Natural Resource Sciences, University of Nebraska-Lincoln, Lincoln, NE 68583-0758, USA

\begin{abstract}
Stable isotopes of nitrogen were used to identify sources of nitrate contamination to groundwater on Cheju, a subtropical island off the southernmost tip of the Korean peninsula. The $\delta^{15} \mathrm{~N}$ ranges of potential animal waste and fertilizer $\mathrm{N}$ sources on the island were similar to those previously reported in the USA, Europe, and Africa. A total of 108 soil pore water samples were collected between January and October 1998 from fertilized soils below soybean fields and citrus groves. Low concentrations of nitrate below fertilized soybean fields indicated that it is highly unlikely that these fields contribute significant $\mathrm{N}$ to the groundwater problem on Cheju. The low average $\delta^{15} \mathrm{~N}$ value of $+1.9 \pm$ $2.1 \%$ in pore-water nitrate and the even lower $\delta^{15} \mathrm{~N}$ values after the fertilizer flush suggest that low levels of mineralized $\mathrm{N}$ are released from the bean roots or nodules. Located in the western region, the bean fields received less rainfall than the citrus groves in the southern region. Pore-water below citrus trees contained considerably higher nitrate levels, and the $\delta^{15} \mathrm{~N}$ values became cyclically enriched after the initial fertilizer flush. Although denitrification can be expected in warm, wet soils high in organic-C content in the southern region of Cheju, it was not supported by porewater or groundwater chemistry. Isotopic enrichment in soil pore-water is caused primarily by volatilization of ammonium-based fertilizers. Since isotopic fractionation in the soils did not exceed $+4 \%$, source identification was possible. The dominant sources of nitrate contamination to Cheju groundwater were identified as commercial N-fertilizer applications to citrus, and, in the Seogwipo municipality, human or animal wastes.
\end{abstract}

Keywords: ammonia, ground water, $\delta^{15} \mathrm{~N}$, nitrate, pore water, volatilization

\section{Introduction}

Groundwater contamination by nitrate $\left(\mathrm{NO}_{3}^{-}\right)$is a global problem and is most often associated with leachates derived from fertilizers or animal and human wastes (Spalding and Exner, 1993). Because $\mathrm{NO}_{3}{ }^{-}$is known to cause methemoglobenemia in infants, the US Environmental Protection Agency has specified $10 \mathrm{mg}$ $\mathrm{NO}_{3}-\mathrm{N}^{-1}$ as the maximum contaminant level (MCL) under the Safe Drinking Water Act (Federal Register, 1975). This limit has been adopted by the South Korean
Department of Environmental Preservation. In a study of 780 wells located throughout the Republic of South Korea, 101 wells contained $\mathrm{NO}_{3}-\mathrm{N}$ levels that exceeded the MCL (Shin, 1996). Kumazawa (1996) reported that the main island of Japan and several islands in the Japanese Archipelago have extensive agricultural areas with elevated groundwater nitrate concentrations. Green et al. (1998) reported that $67 \%$ of the sampled groundwater from the intensively grazed island of Jersey in the British Channel was adversely impacted by $\mathrm{NO}_{3}{ }^{-}$concentrations in excess of the MCL. Like Jersey and the Jap- 
anese islands, agriculture is intensive on Cheju and its groundwater quality is threatened by nitrate contamination. The island is the most adversely nitrate-impacted groundwater province in Korea (Shin, 1996). Globally, many islanders are solely dependent on shallow groundwater supplies that are threatened by $\mathrm{N}$ leachates from intensive agriculture.

In oxidizing environments, agronomic-N leachates from commercial fertilizer and mineralized soil organic matter can be isotopically differentiated from those originating from animal waste (Berndt, 1990; Exner \& Spalding, 1994; Gormly \& Spalding, 1979; Kreitler, 1975; Komor \& Anderson, 1993). Transformations of nitrate and ammonia in soils and groundwater generally are dominated by isotopic enrichment of the substrate, defined as $\varepsilon=1-\alpha$, in which the rate constant for the compound with the heavier mass, $k_{1}$, is slower than that of the compound with the lighter mass, $k_{2}$, such that $k_{1} / k_{2}=\alpha$ and $\alpha$ is $<1$. During the volatilization of $\mathrm{NH}_{3}$ formed via the enzymatic hydrolysis of urea in animal and human wastes, enrichment is caused by an equilibrium isotope effect between aqueous $\mathrm{NH}_{4}{ }^{+}$and gaseous $\mathrm{NH}_{3}$ and has an isotope equilibrium constant of 1.034 (Kreitler, 1975). Volatilization losses are minimized when anhydrous $\mathrm{NH}_{3}$ used as a starter fertilizer is injected into the soil, and in most cases, the nitrate signature of the impacted groundwater nitrate is only slightly enriched relative to the light signature of the anhydrous fertilizer (Gormly \& Spalding, 1979). In oxidizing soil and water environments, the residual applied NH4-N is quickly nitrified to $\mathrm{NO}_{3}-\mathrm{N}$ and, since the nitrification reaction goes to completion, the isotopic signature of the reactant is assumed by the product.

A kinetic isotope effect during denitrification causes a similar enrichment in the residual $\mathrm{NO}_{3}{ }^{-}$. Isotopic enrichment of nitrate- $\mathrm{N}$ during denitrification has been reported in soils (Chien et al., 1977) and in groundwater (Mariotti et al., 1988; Smith et al., 1991; Spalding et al., 1993). In the process facultative anaerobes utilize organic carbon $\left(\mathrm{CH}_{2} \mathrm{O}\right)$ as an electron donor and when $\mathrm{O}_{2}$ is limiting, $\mathrm{NO}_{3}{ }^{-}$becomes the electron acceptor. The generalized formula for heterotrophic denitrification is:

$$
5 \mathrm{CH}_{2} \mathrm{O}+4 \mathrm{NO}_{3}{ }^{-}+4 \mathrm{H}^{+} \rightarrow 5 \mathrm{CO}_{2}+2 \mathrm{~N}_{2}+7 \mathrm{H}_{2} \mathrm{O}
$$

Dissimilatory nitrate reduction to ammonia (DNRA) can occur when the molar concentration of assimilable $\mathrm{C}$ exceeds that of the nitrate (Korom, 1992):

$$
2 \mathrm{H}^{+}+\mathrm{NO}_{3}{ }^{-}+2 \mathrm{CH}_{2} \mathrm{O} \rightarrow \mathrm{NH}_{4}^{+}+2 \mathrm{CO}_{2}+\mathrm{H}_{2} \mathrm{O}
$$

Where both heterotrophic reduction and DNRA reduction pathways occur, heterotrophic denitrification is more significant (Tiedje, 1994).

Suction lysimeters are used to extract percolate from soils within and below the root zone. Measurement of pore-water nitrate concentrations and $\mathrm{N}$-isotope values ascertain the extent of isotopic fractionation in upper soil horizons and whether stable $\mathrm{N}$-isotopes are an appropriate tool for source assessment.

The objectives of this investigation were: (1) to determine the extent of $\mathrm{N}$-isotope fractionation in warm, wet subtropical soils; (2) to compare $\delta^{15} \mathrm{~N}$ signatures of nitrate extracted from soil pore water below citrus and soybean agriculture to those in the island's municipal wells; and (3) to determine whether leachate from fertilizer-N used in subtropical agriculture is a major contributor to Cheju Island's high groundwater nitrate.

\section{Background}

Cheju Island lies about $145 \mathrm{~km}$ from the southwest corner of the Korean Peninsula and has a total surface area of 182580 ha (Figure 1). About 30\% of the island's $\sim 515,000$ inhabitants live on farms, i.e., twice the farmer density of the Korean mainland (Shin, 1996).

About 54,500 ha or $30 \%$ of the island is cropped. Fertile, dark brown and black, silt loam soils classified as andisols (Shin, 1996) are the primary weathering products of the volcanic rock. A survey of more than 41,000 ha of Cheju farmland revealed a regional average soil organic matter ranging from 4.9 to $12.3 \%$ and averaging $8 \%$ (Hyun, 1996). Because the farmland has an abundance of large volcanic rocks and the island is very windy, rock walls $1-2 \mathrm{~m}$ have been constructed around the cropped fields. The walls serve as wind breaks, and separate the farmland into thousands of fields, each usually less than 5 ha. These cropped fields support a thriving agricultural industry. Tangerines represent $59 \%$ of the island's agricultural production. Tangerine orchards cover $39.9 \%$ of the cropped area, while on an additional $4.1 \%$ of the cultivated area tangerines are grown in specially constructed greenhouses (Shin, 1996).

Annual average coastal temperatures are $15.2^{\circ} \mathrm{C}$ at Cheju City on the island's north side and $15.9^{\circ} \mathrm{C}$ at Seogwipo City on the south side (Shin, 1996). The northern portion of the island occasionally has near freezing 


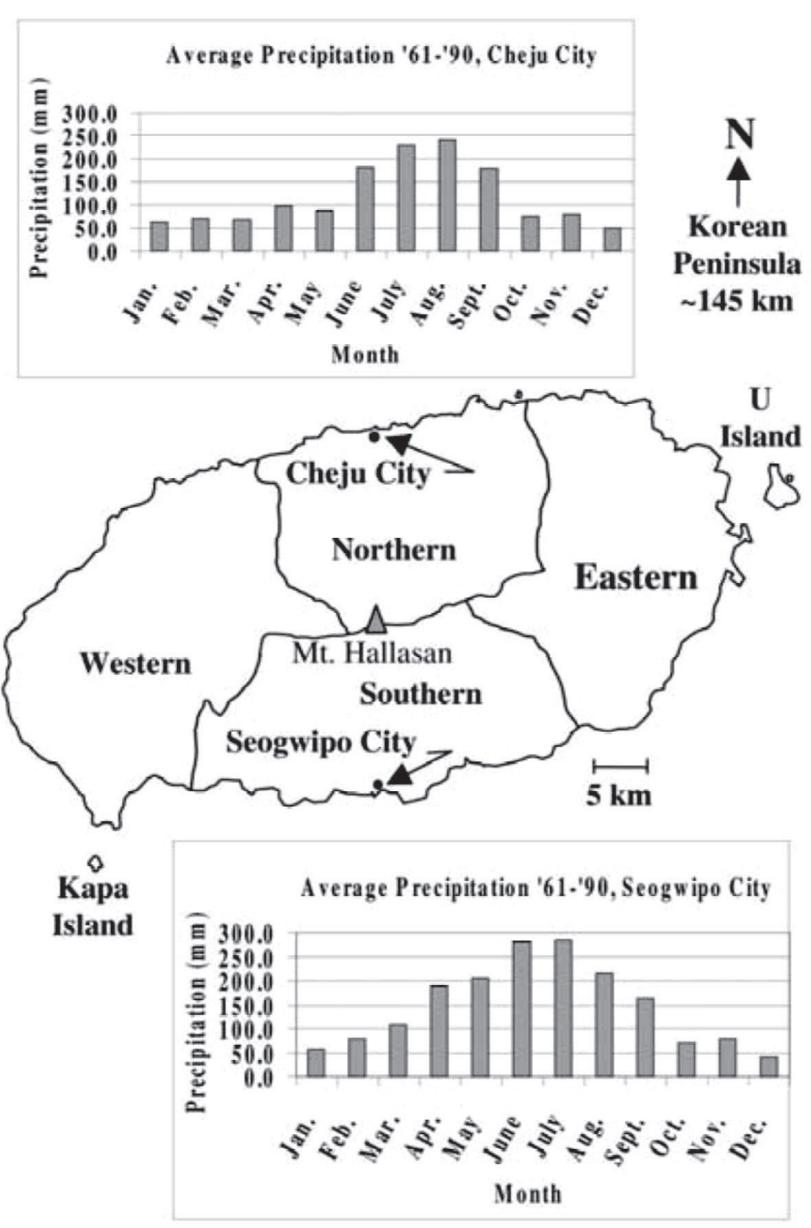

Figure 1. Geographic zones on Cheju Island (Kim et al., 1996) and historical precipitation data.

conditions during January, which is the coldest month with temperatures averaging $5.2^{\circ} \mathrm{C}$ in Cheju City. Precipitation is usually plentiful throughout the island. However, it is not uniform (Figure 1) and greatly influenced by orogenic effects of Mt. Hallasan, the 1783-m volcanic peak in the island's center. Thirty-year precipitation averages (1961-1990) indicate that Cheju City received $1423.7 \mathrm{~mm}$ year $^{-1}$ and Seogwipo City 1771.4. Average precipitation is two times higher during the warm season from April to September than in the cooler months. Precipitation increases with altitude at a rate of 110 mm/100 m (Shin, 1996).

Preferential flow through channels in the layered basalts of the unsaturated zone at estimated rates of $10 \mathrm{~m}$ year $^{-1}$ permit rapid groundwater recharge. Large lava tunnels are known to provide deep flow channels in several areas. Depth to groundwater level varies from 10 to $100 \mathrm{~m}$ in the coastal uplands where most of the samples were collected.
Kim et al. (1996) measured $\mathrm{pH}$, major ions, and $\mathrm{NO}_{3}$ $\mathrm{N}$ in 99 groundwater samples during a water quality investigation. Their results indicate that the water quality was quite different in each of the geographic subdivisions as shown in Figure 2. They reported saltwater encroachment into a thin fresh water lens in the eastern zone and $\mathrm{NO}_{3}-\mathrm{N}$ contamination in the western and southern zones and subdivision $\mathrm{Cc}$ in the northern zone. Highest $\mathrm{NO}_{3}-\mathrm{N}$ concentrations $\left(>30 \mathrm{mg} \mathrm{l}^{-1}\right)$ were recorded in the subdivisions $\mathrm{Tj}, \mathrm{Ad}, \mathrm{Sg}$ and $\mathrm{Nw}$ in the western and southern zones, respectively. $\mathrm{NO}_{3}-\mathrm{N}$ concentrations averaged $6.6 \mathrm{mg} \mathrm{l}^{-1}$ in the western zone and 8.5 in the southern zone.

\section{Materials and methods}

Sampling methods

In early July 1997, 21 lysimeters were installed at seven sites in upland soils along the island's perimeter. Soil Moisture Equipment ${ }^{\mathrm{TM}}$ Model \#1920 pressurevacuum lysimeters (Figure 3) were placed in manually dug 1-m deep holes below the drip line of mature citrus trees, and in trenches $2.5 \mathrm{~m}$ apart and $1 \mathrm{~m}$ deep in soybean fields. Rocks and pebbles were removed from the excavated soil, and the cleanest fill was placed around the porous ceramic cup at the bottom of the HDPE lysimeter chamber. The remaining void was backfilled with rock-free soil from the excavated hole. The soil was tamped to moderately compact the fill. PVC risers 7.5 $\mathrm{cm}$ in diameter and $10 \mathrm{~cm}$ long were placed over the access tubes and capped to protect the coiled access tubes from vandalism and preferential flows.

The lysimeters were cleaned out several times during 1997; however, no sample collection occurred until January 1998. Briefly, pore water was collected by attaching a precleaned, 250-ml glass side-arm flask to a vacuum pump manifold, connecting the sampling line to a tube inserted through the rubber stopper in the flask, and, with the valve closest to the flask shut, applying a vacuum to the vacuum line for approximately one hour. Then the vacuum line valve was closed, and the sample line opened allowing water to fill the bottom of the flask (Figure 3). The soil pore water was transferred to 250-ml polypropylene bottles, acidified with $\mathrm{H}_{2} \mathrm{SO}_{4}$, and frozen for air-express shipment to the University of NebraskaLincoln (USA) Water Sciences Laboratory (WSL).

Eighteen municipal wells, located in the urban areas of Cheju City and Seogwipo City, rural towns, and in 


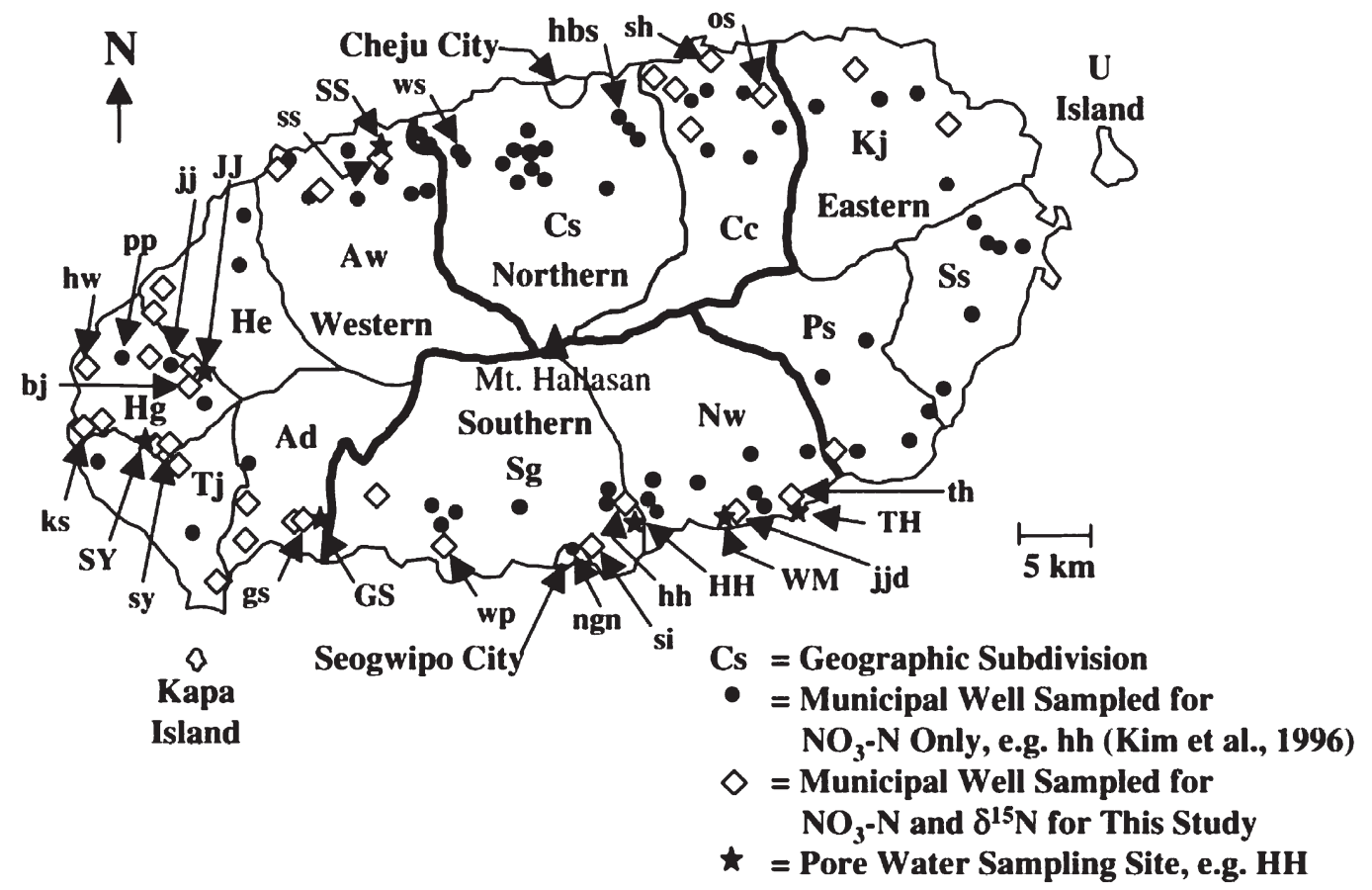

Figure 2. Location of sampling sites.

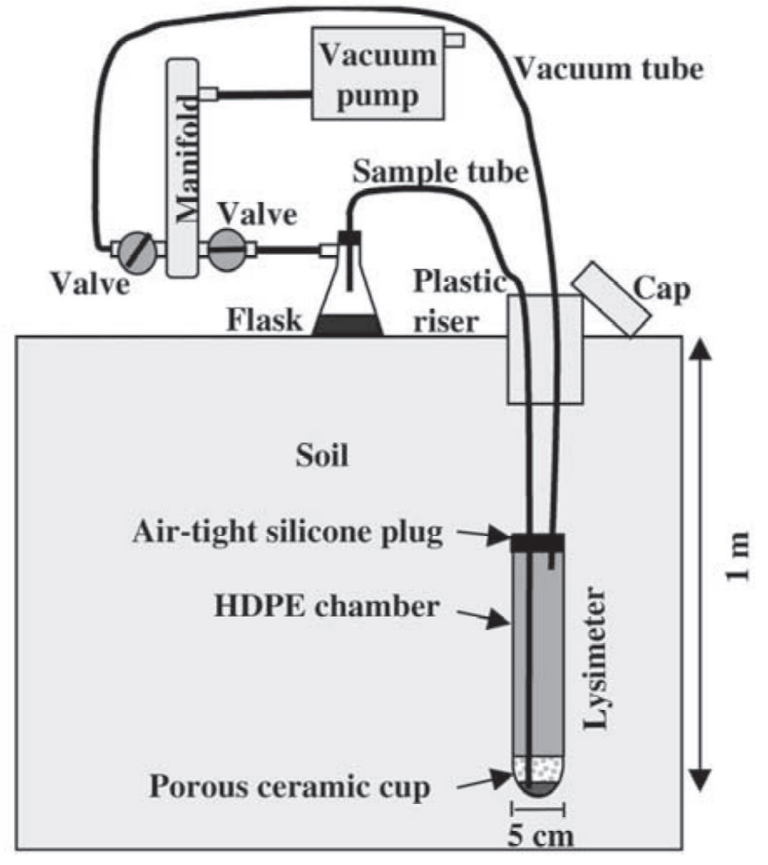

Figure 3. Soil pore water sampling system.

cropped fields were sampled from faucets on the well heads. Samples were collected in 1-1 polyethylene containers, acid preserved, and shipped to the WSL.
Several different commercial $\mathrm{N}$-fertilizers as well as samples of rape seed cake and animal manure were also received by the WSL for analysis.

\section{Analytical methods}

Nitrate- $\mathrm{N}$ and ammonia-N concentrations were determined in water by steam distillation followed by acid titration (Bremner \& Keeney, 1965). Preparation of commercial N-fertilizers, rape seed, and manure for N-isotope analysis followed the methods outlined in Gormly and Spalding (1979). The $\left(\mathrm{NH}_{4}\right)_{2} \mathrm{SO}_{4}$ was subsequently oxidized to $\mathrm{N}_{2}$ in a vacuum preparation system designed after that of Kreitler (1975). Purified $\mathrm{N}_{2}$ samples were analyzed with a dual inlet isotope ratio mass spectrometer (VG Optima). The $\delta^{15} \mathrm{~N}$ values were defined by the expression:

$$
\delta^{15} \mathrm{~N}(\% \mathrm{o})=\frac{\left({ }^{15} \mathrm{~N} /{ }^{14} \mathrm{~N}\right)_{\text {sample }}-\left({ }^{15} \mathrm{~N} /{ }^{14} \mathrm{~N}\right)_{\text {standard }}}{\left({ }^{15} \mathrm{~N} /{ }^{14} \mathrm{~N}\right)_{\text {standard }}} \times 1000
$$

These $\delta^{15} \mathrm{~N}$ values were determined by the procedure of Bremner \& Edwards (1965) and Miyaka \& Wada (1967). The primary standard was atmospheric $\mathrm{N}_{2}$, prepared according to the procedure of Cline (1973). The absolute ratio of ${ }^{14} \mathrm{~N} /{ }^{15} \mathrm{~N}$ in atmospheric $\mathrm{N}_{2}$ was first found to be $272.0 \pm 0.3$, an ${ }^{14} \mathrm{~N}$ abundance of $99.63 \%$, with $0.37 \%{ }^{15} \mathrm{~N}$ 


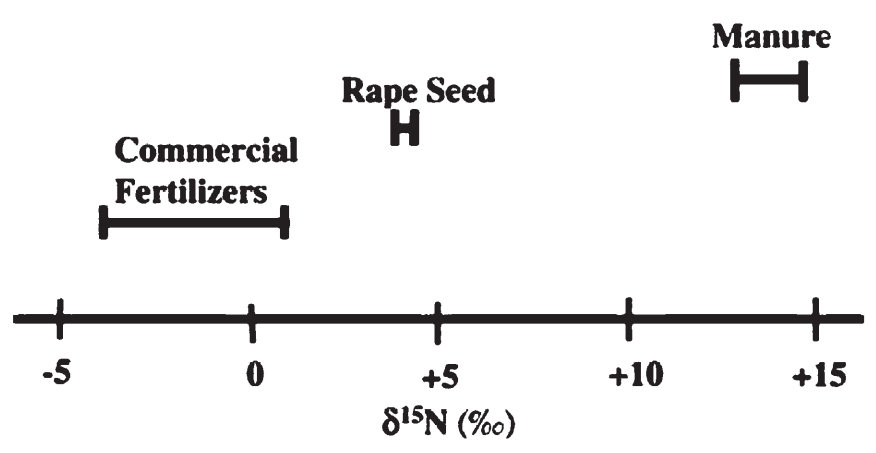

Figure 4. $\delta^{15} \mathrm{~N}$ signature of potential nitrogen sources on Cheju Island.

(Junk \& Svec, 1958). They also determined that the abundance was invariant of sampling location. More refined abundance measurements indicate an ${ }^{15} \mathrm{~N}$ abundance of $0.3663 \%$ (Létolle, 1980). The $\delta^{15} \mathrm{~N}$ values presented here are relative to measured atmospheric $\mathrm{N}_{2}{ }^{15} \mathrm{~N} /{ }^{14} \mathrm{~N}$ ratios. The working standard was ultra pure $(99.999 \%)$ carrier grade tank $\mathrm{N}_{2}$. The calculated standard deviation for 216 preparations of the working standard was $0.07 \%$. The $\delta^{15} \mathrm{~N}$ of $\left(\mathrm{NH}_{4}\right)_{2} \mathrm{SO}_{4}$, another USGS working standard, had a mean of $-2.2 \pm 0.17 \%$ or 10 determinations. In a recent USGS-sponsored accuracy crosscheck program, the WSL's $\delta^{15} \mathrm{~N}$ values were well within acceptable limits (Böhlke and Coplen, 1995).

\section{Results and discussion}

\section{Potential N sources}

Figure 4 depicts the $\delta^{15} \mathrm{~N}$ values of major nitrate sources that have the potential to contaminate Cheju Island groundwater. The $\delta^{15} \mathrm{~N}$ values of Korean commercial fertilizers and pig and chicken manure on Cheju Island are within ranges determined in the USA, France, South Africa, and Germany (Spalding et al., 1982). The use of rape seed cake as fertilizer on Cheju is apparently unique. Rape seed cake is the compacted seed, which is formed during pressure squeezing the seeds to extract oil. Rape fields are fertilized at $350 \mathrm{~kg} \mathrm{~N} \mathrm{ha}^{-1}$, and the seeds have a high $\mathrm{N}$ content. The relatively low $\delta^{15} \mathrm{~N}$ values of rape seed cake suggest that isotope fractionation of fertilizer-derived $\mathrm{N}$ is quite limited during plant uptake and seed processing. The difference between $\delta^{15} \mathrm{~N}$ values for commercial fertilizer and animal waste is sufficient for source discrimination.

\section{Groundwater N sources}

In June 1996, $\mathrm{NO}_{3}-\mathrm{N}$ concentrations in the 18 municipal wells ranged from 2.1 to 20.2 and averaged $12.5 \pm$ $5.8 \mathrm{mg} \mathrm{l}^{-1}$. Values for $\delta^{15} \mathrm{~N}$ of $\mathrm{NO}_{3}-\mathrm{N}$ ranged from +3.6 to $+10.2 \%$ ond averaged $+5.9 \pm 1.7 \%$. A few wells were resampled in July and 13 wells were resampled in November. While in some wells $\mathrm{NO}_{3}-\mathrm{N}$ concentrations fluctuated widely, the $\delta^{15} \mathrm{~N}$ values remained relatively constant during the 4-5 months (Table 1). The data suggest that the individual wells were impacted by the same source, regardless of changes in $\mathrm{NO}_{3}-\mathrm{N}$ concentrations. The concentration fluctuations probably were related to seasonal changes in recharge or capture zone with the latter a result of changes in pumping demand.

Variations in the natural abundance of stable nitrogen isotopes have been used successfully to semiquantitatively differentiate between nonpoint source areas impacted by agronomic and waste sources of nitrate in groundwater (Böhlke \& Denver, 1995; Exner \& Spalding, 1994; Gormly \& Spalding, 1979). The geographical distribution of $\delta^{15} \mathrm{~N}$ values for groundwater $\mathrm{NO}_{3}-\mathrm{N}$ suggests that with the exception of two wells there is one dominant source of nitrate contamination on Cheju (Table 1). The enriched $\delta^{15} \mathrm{~N}$ in the two wells (Ngn, Si) near Seogwipo City suggests the source is human waste. Both municipal wells are located in the most densely urbanized area sampled, and the groundwater could be contaminated by leachates from human waste-N seeping from rock-lined sewer drains along the city streets. Like animal wastes, the $\delta^{15} \mathrm{~N}$ values of $\mathrm{NO}_{3}{ }^{-}$derived from human waste are enriched (Aravena et al., 1993). The remaining wells on the island are impacted by agronomic sources that include commercial fertilizers and to a lesser extent animal waste. The island's cooler north side has higher average $\delta^{15} \mathrm{~N}$ values $(+6.8 \%$ o) than the rest of the island, which with the exception of the two wells near Seogwiopo City (Ngn and $\mathrm{Si}$ ) in the southern zone, averaged $+5.1 \%$. A similar average $\delta^{15} \mathrm{~N}$ value of $5.3 \%$ occurred in the western zone. Reported heavier applications of manure by farmers on the north side of Cheju Island (Kim et al., 1996) may have resulted in a greater contribution of animal waste $\mathrm{N}$ to the regional groundwater. However, with respect to electrical conductivity, $\mathrm{Cl}^{-}$and $\mathrm{Na}^{+}$, the northern groundwater is not significantly different from that in the south. Berndt (1990) and Exner \& Spalding (1994) have shown that the $\delta^{15} \mathrm{~N}_{-} \mathrm{NO}_{3}{ }^{-}$ in groundwater containing mixtures of animal and human waste and commercial fertilizer increased in pro- 
Table 1. Nitrate-N concentrations and $\delta^{15} \mathrm{~N}$ of nitrate in eighteen municipal wells on Cheju Island

\begin{tabular}{|c|c|c|c|c|c|c|c|c|}
\hline Well ID & Zone & $\begin{array}{l}\text { June } 1996 \\
\text { mg } \mathrm{NO}_{3}-\mathrm{N} \mathrm{l}^{-1}\end{array}$ & $\begin{array}{l}\text { June } 1996 \\
\delta^{15} \mathrm{~N}(\% \circ)\end{array}$ & $\begin{array}{l}\text { July } 1996 \\
\text { mg NO}_{3}-\mathrm{N} \mathrm{l}^{-1}\end{array}$ & $\begin{array}{l}\text { July } 1996 \\
\delta^{15} \mathrm{~N}(\% \text { o })\end{array}$ & $\begin{array}{l}\text { Nov } 1996 \\
\mathrm{mg} \mathrm{NO}_{3}-\mathrm{N} \mathrm{l}^{-1}\end{array}$ & $\begin{array}{l}\text { Nov } 1996 \\
\delta^{15} \mathrm{~N}(\% \text { (\%) }\end{array}$ & $\begin{array}{l}\text { Avg } \pm \text { SD } \\
\delta^{15} \mathrm{~N}(\% \text { o })\end{array}$ \\
\hline Hbs & Northern & 8.0 & 6.2 & - & - & 8.7 & 7.3 & $6.8 \pm 0.8$ \\
\hline Ws & Northern & 2.1 & 8.9 & 4.6 & 8.6 & 2.2 & 7.6 & $8.4 \pm 0.7$ \\
\hline Sh & Northern & 15.8 & 7.1 & 7.1 & 6.1 & 18.4 & 6.3 & $6.5 \pm 0.5$ \\
\hline Os & Northern & 8.9 & 4.7 & 8.6 & 6.4 & 8.7 & 5.7 & $5.6 \pm 0.8$ \\
\hline Jjd & Southern & 20.2 & 4.4 & 17.2 & 5.0 & 11.3 & 4.6 & $4.7 \pm 0.3$ \\
\hline $\mathrm{Hh}$ & Southern & 19.7 & 5.1 & - & - & - & - & 5.1 \\
\hline Wp & Southern & 14.8 & 5.2 & - & - & - & - & 5.2 \\
\hline $\mathrm{Si}$ & Southern & 12.2 & 9.9 & - & - & 12.4 & 10.2 & $10.0 \pm 0.2$ \\
\hline Ngn & Southern & 7.5 & 7.8 & - & - & 8.3 & 9.0 & $8.4 \pm 0.8$ \\
\hline $\mathrm{Ks}$ & Western & 11.8 & 3.6 & 13.6 & 4.0 & 14.3 & 4.4 & $4.0 \pm 0.4$ \\
\hline $\mathrm{Jj}$ & Western & 2.6 & 4.6 & 4.9 & 4.4 & 2.9 & 4.7 & $4.6 \pm 0.2$ \\
\hline $\mathrm{Hw}$ & Western & 15.0 & 5.2 & 18.5 & 4.9 & 16.3 & 5.8 & $5.3 \pm 0.4$ \\
\hline $\mathrm{Pp}$ & Western & 4.1 & 5.8 & 4.6 & 4.2 & 4.6 & 5.5 & $5.2 \pm 0.9$ \\
\hline Sy & Western & 19.8 & 5.3 & 11.4 & 4.9 & 7.8 & 4.8 & $5.0 \pm 0.3$ \\
\hline
\end{tabular}

portion to the increase in applied waste N. Nitrate leachates derived from the application of animal waste to crops may be responsible for the approximately $2 \%$ o difference in average $\delta^{15} \mathrm{~N}$ values between the northern and southern and western zones of Cheju Island.

Pore water

Nitrate concentrations ranged from $<0.1$ to $21.3 \mathrm{mg}$ $\mathrm{NO}_{3}-\mathrm{N}^{-1}$ and averaged $5.1 \mathrm{mg} \mathrm{NO}_{3}-\mathrm{N} \mathrm{l}^{-1}$ in pore water from $\sim 1 \mathrm{~m}$ below cropped soybean fields and ranged from 4.0 to $64.3 \mathrm{mg} \mathrm{NO}_{3}-\mathrm{N}^{-1}$ and averaged $30.71 \mathrm{~m}$ below the drip line of citrus trees. Generally, granular 21-17-17 (NPK) fertilizer with $\mathrm{N}$ as urea is preferred for the citrus trees. Normally, it is applied during spring (March) and late fall (October or early November). Annual fertilization rates range from 275 to $387 \mathrm{~kg} \mathrm{~N} \mathrm{ha}^{-1}$. In June, supplemental $\mathrm{N}$ and $\mathrm{K}$ are applied as urea and $\mathrm{KCl}$, respectively. Soybeans have the ability to fix atmospheric $\mathrm{N}_{2}$ and do not normally require supplemental $\mathrm{N}$. On Cheju, however, starter $\mathrm{N}$ is applied to soybeans and also to the barley crop that proceeds it. Granular 10-16-10 (NPK) fertilizer is applied to barley in October at a rate of $126 \mathrm{~kg} \mathrm{~N} \mathrm{ha}^{-1}$, and in May granular 8-14-12 (NPK) fertilizer to the soybean crop at a rate of $147 \mathrm{~kg} \mathrm{~N}$ $\mathrm{ha}^{-1}$. In the southern regions of the USA soybeans fix an average of $145 \mathrm{~kg} \mathrm{~N} \mathrm{ha}^{-1}$ (Schepers \& Mosier, 1991).

Interestingly, the average $\delta^{15} \mathrm{~N}$ value of $+1.9 \pm 2.1 \%$ o below the bean fields was significantly lower than the average value of $+4.3 \pm 2.3 \%$ o $\left(t_{0.001,12,45}=-4.41\right)$ below the drip line of the tangerine trees. Since the $\delta^{15} \mathrm{~N}$ values in the pore water of the bean fields were more depleted when $\mathrm{NO}_{3}-\mathrm{N}$ concentrations were lowest, it is unlikely that fertilizer is the major nitrogen source. There appears to be a low-level $\mathrm{N}$ release from the plant roots or legume nodules. Because there is little, if any, $\mathrm{N}$ isotope fractionation involved in $\mathrm{N}_{2}$ fixation (Kreitler, 1975), nitrification of amines and organic compounds formed from atmospheric $\mathrm{N}$ would be expected to produce nitrate close to or lighter than $0.0 \%$. Thus, $\mathrm{NO}_{3}{ }^{-}$derived from atmospheric $\mathrm{N}_{2}$ fixed within the root zone of beans can be a source of $\mathrm{NO}_{3}{ }^{-}$to the soil pore water and possibly a minor source of groundwater $\mathrm{NO}_{3}{ }^{-}$contamination. The interpretation of the seasonal lysimeter data for pore-water nitrate and $\delta^{15} \mathrm{~N}$ values in the next section further clarifies this concept.

For one soybean site and two citrus sites the presented data in Figures 5-7, respectively, were selected because they provide representative and complete data sets. At site SY (Figure 5), $\mathrm{NO}_{3}-\mathrm{N}$ levels in the pore wa- 

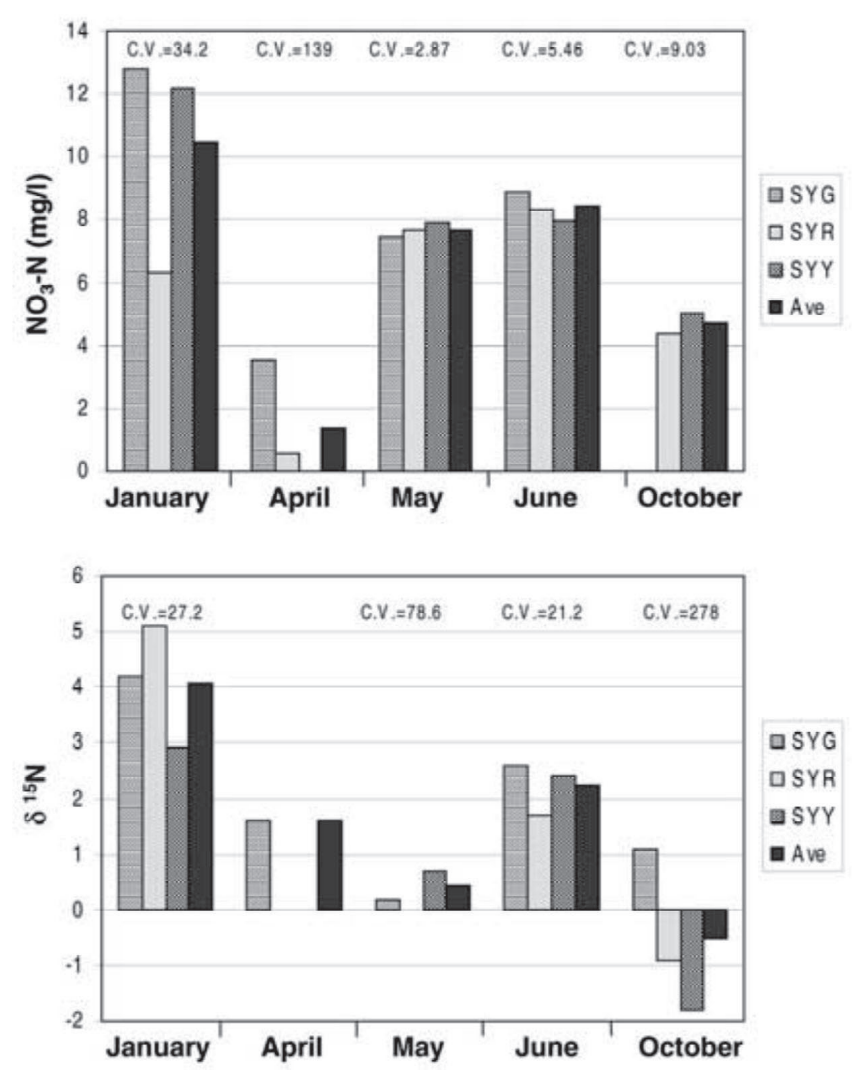

Figure 5. $\mathrm{NO}_{3}-\mathrm{N}$ and $\delta^{15} \mathrm{~N}-\mathrm{NO}_{3}$ below soybean field SY. Each individual lysimeter is identified by the third letter in the site code, i.e. SYY.

ter ranged from $<0.1$ to $12.8 \mathrm{mg} 1^{-1}$. Although pore-water $\mathrm{NO}_{3}-\mathrm{N}$ concentrations were consistently much lower than those below the citrus groves (Figures 6 and 7), they appeared cyclic, being lowest in April and October immediately before preplant fertilization and higher in January, May, and June. Nitrate leachates from starter fertilizers were observed in May and June during the rainy season and in the dry season (Figure 1) during January. In months when pore-water NO3-N concentrations were lowest, the $\delta^{15} \mathrm{~N}$ values were most depleted, ranging from -1.8 to $+1.6 \%$. $\mathrm{NH}_{4}-\mathrm{N}$ concentrations below soybeans fields were too low (generally $<0.5 \mathrm{mg} \mathrm{l}^{-1}$ ) for isotope analysis. Low concentrations and highly depleted $\mathrm{N}$-isotopic values suggest that a large proportion of $\mathrm{NO}_{3}{ }^{-}$is derived from mineralization of plant roots and fixation nodules. It has been well established that soybeans planted in rotation with corn provide residual soil $\mathrm{N}$ that is mineralized during the next planting and utilized by the crop (Varvel \& Peterson, 1990). Immediately after fertilization $\mathrm{NO}_{3}-\mathrm{N}$ was more concentrated and the $\delta^{15} \mathrm{~N}$ values were more enriched, ranging from +0.45 to $+5.1 \%$. The slight enrichment is presumed a result of volatilization and denitrification.
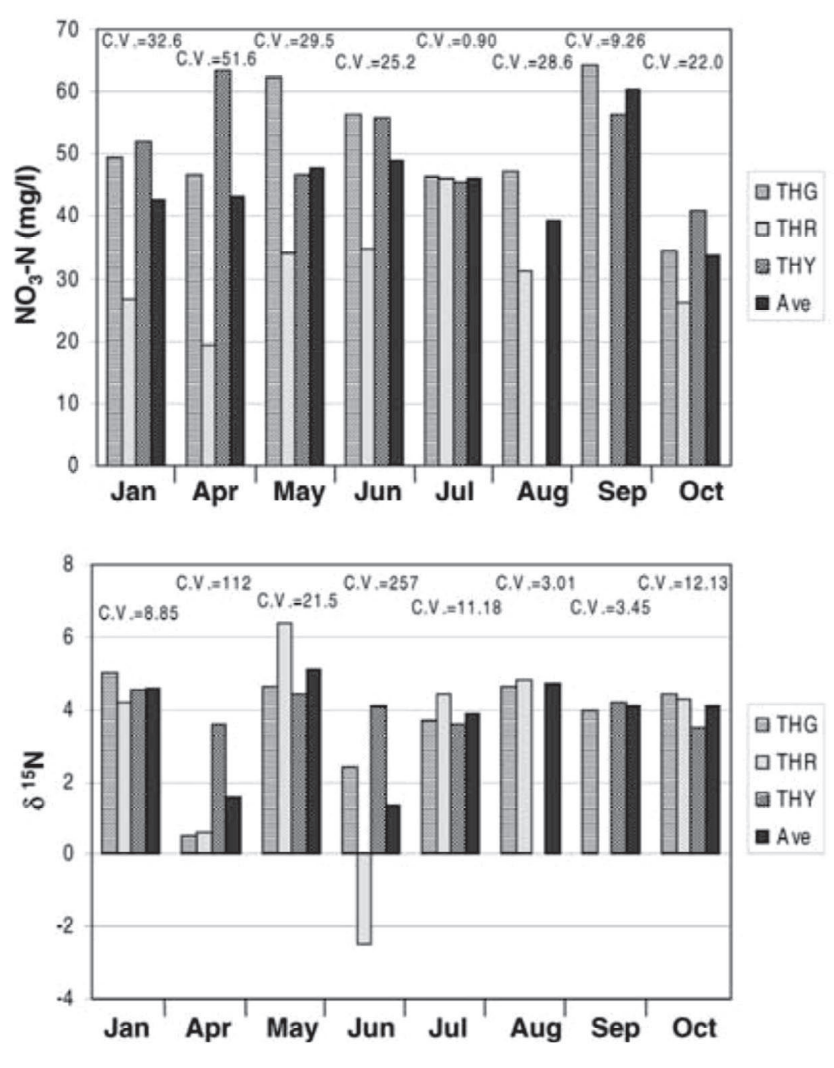

Figure 6. $\mathrm{NO}_{3}-\mathrm{N}$ and $\delta^{15} \mathrm{~N}-\mathrm{NO}_{3}$ below citrus grove TH. Each individual lysimeter is identified by the third letter in the site code, i.e., THG.

Below citrus, cyclic pore-water $\mathrm{NO}_{3}-\mathrm{N}$ variability (Figures 6 and 7) was less pronounced and appeared related to the increased frequency of pulsed flushes from recent $\mathrm{N}$-fertilizer applications during the wet season. The two citrus sites TH and HH (Figures 6 and 7), with the most complete $\mathrm{NO}_{3}-\mathrm{N}$ and $\delta^{15} \mathrm{~N}$ data, are located in the Seogwipo area (Figure 2). Although the $\mathrm{NO}_{3}-\mathrm{N}$ trends and $\delta^{15} \mathrm{~N}$ values from the drier western region are similar to those from the south-central lysimeter sites, during several months one or more lysimeters from sites in the western region contained insufficient pore water for analysis. $\mathrm{NH}_{4}-\mathrm{N}$ concentrations were generally below $2.0 \mathrm{mg} \mathrm{l}^{-1}$ except during May and June, when concentrations were as high as $8.6 \mathrm{mg} \mathrm{l}^{-1}$. High concentrations of ammonium in some lysimeters suggest that preferential flow occurs at some sites or the sites for ammonium exchange are occupied, and ammonia from the recent fertilizer application is flushed $1 \mathrm{~m}$ below ground surface. Sites with high ammonium concentrations were restricted almost entirely to the southcentral region where precipitation is higher. The $\delta^{15} \mathrm{~N}$ values for $\mathrm{NH}_{4}-\mathrm{N}$ ranged from +0.8 to $+2.5 \%$ which is indicative of fertilizer origin. The occurrence of $\mathrm{NH}_{4}-\mathrm{N}$ 

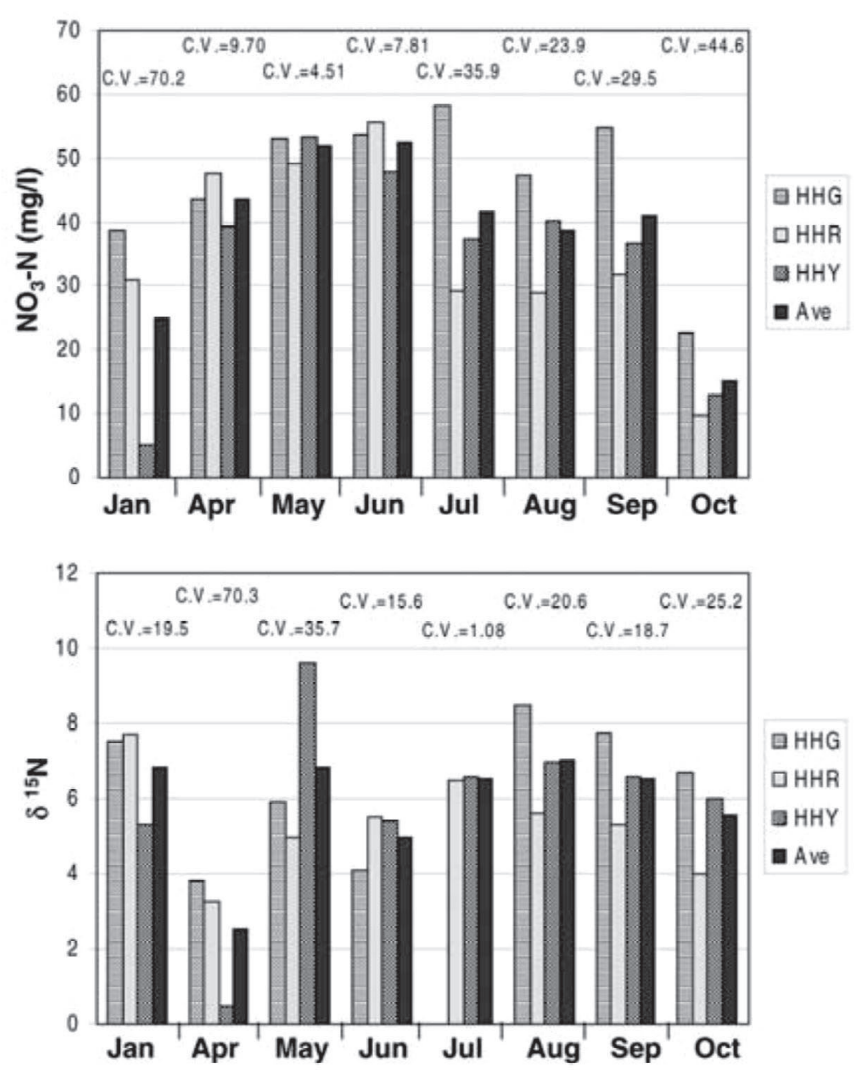

Figure 7. $\mathrm{NO}_{3}-\mathrm{N}$ and $\delta^{15} \mathrm{~N}-\mathrm{NO}_{3}$ below citrus grove $\mathrm{HH}$. Each individual lysimeter is identified by the third letter in the site code, i.e. HHR.

coincided with the post-application flush of fertilizer $\mathrm{N}$. In successive months after fertilization, $\mathrm{NH}_{4}-\mathrm{N}$ concentrations decreased and heterotrophic denitrification resulted in isotopic enrichment of the residual $\mathrm{NO}_{3}-\mathrm{N}$. The depleted $\delta^{15} \mathrm{~N}$ of the $\mathrm{NH}_{4}-\mathrm{N}$ and the low $\mathrm{NH}_{4}-\mathrm{N}$ concentrations suggest that it is flushed from the fertilizer and is not a product of DNRA.

Pore-water $\mathrm{NO}_{3}-\mathrm{N}$ concentrations usually were highest in the warm, wet season and averaged from 30 to $60 \mathrm{mg} \mathrm{l}^{-1}$. Highest average concentrations usually were in June after early summer $\mathrm{N}$-fertilization; however, in some lysimeters, at sites where $\mathrm{NO}_{3}{ }^{-}$was depleted by leaching or crop uptake, abrupt increases in concentration were also noted in April after spring fertilization. Immediately after $\mathrm{N}$-fertilizer applications in the months of March and May/June, the $\delta^{15} \mathrm{~N}$ values of the pore-water $\mathrm{NO}_{3}{ }^{-}$at all monitored sites were low relative to the other months. Occurrence of a $\mathrm{NO}_{3}{ }^{-}$flush immediately after fertilization together with high porewater $\mathrm{NO}_{3}-\mathrm{N}$ concentrations and low $\delta^{15} \mathrm{~N}$ values indicate that $\mathrm{N}$-fertilizer is the main component in leach- ate below Cheju citrus groves. In a mixed source area of southern Indiana, nitrate concentrations and their respective $\delta^{15} \mathrm{~N}$ values showed that as larger amounts of fertilizer-N leachate were extracted by the lysimeters the $\delta^{15} \mathrm{~N}$ values became more depleted (Igbal et al., 1997). Their data suggested that the timing and intensity of storms after $\mathrm{N}$-fertilization strongly influenced the $\mathrm{N}$ isotope composition of the nitrate in soil pore water and groundwater.

The enrichment in $\delta^{15} \mathrm{~N}$ values after the initial $\mathrm{N}$ fertilizer flush indicates that isotopic fractionation occurs relatively fast. Because the $\mathrm{N}$-fertilizer is in the form of urea, ammonia is produced via hydrolysis and then nitrified in the topsoil. Volatilization-dominated fractionation is expected to occur during the first week after fertilization, as the conversion is by a rapid enzymatic reaction which in warm climates usually goes to completion within a week after urea application. High $\mathrm{pH}$ levels, from 7.6 to 8.0 in the island's groundwater (Kim et al., 1996), suggest that recharge is slightly basic and ammonia volatilization would occur after irrigating recently fertilized soils. In general, the longer the residence of the fertilizer- $\mathrm{N}$ in the soils, the more enriched the $\delta^{15} \mathrm{~N}$ values become. Although the authors presume that the enrichment resulted from volatilization of $\mathrm{NH}_{3}$, denitrification cannot be totally eliminated. In the Seogwipo region, the warm climate, abundant rainfall, and 9.5\% organic content of these dark-colored soils (Hyun, 1996) constitute a favorable environment for denitrification. Yet, the relationship between $\delta^{15} \mathrm{~N}$ values and $\mathrm{NO}_{3}-\mathrm{N}$ concentrations in pore water below citrus groves at Seogwipo lysimeter sites TH $(r=+0.19, n=23)$ and $\mathrm{HH}(r=+0.10, n=23)$ does not support denitrification. At the $\mathrm{HH}$ site, a decreasing trend in $\mathrm{NO}_{3}-\mathrm{N}$ occurred during the season; but, the majority of the enrichment in $\delta^{15} \mathrm{~N}$ was restricted to the sampling month immediately following the first depleted $\delta^{15} \mathrm{~N}$ fertilizer pulse and enrichment did not continue in the succeeding months (Figure 7). Several groundwater studies have shown that when denitrification occurs, enrichments in $\delta^{15} \mathrm{~N}$ values are significantly correlated to decreases in nitrate concentrations (Green et al., 1998; Mariotti et al., 1988; Spalding et al., 1993). Reported low $\mathrm{HCO}_{3}{ }^{-}$concentrations in the groundwater of the Seogwipo region (Kim et al., 1996) are also contradictory to known and suspected denitrification areas (Bates \& Spalding, 1998; Green et al., 1998). The combination of three annual Nfertilizer applications and isotopic fractionation of $\mathrm{N}$ primarily by ammonia volatilization appear to keep most pore water $\delta^{15} \mathrm{~N}$ values between +1 and $+6 \%$. 


\section{Conclusions}

The $\mathrm{NO}_{3}{ }^{-}$leachate data below soybean fields indicate only low levels of potential nitrogen contamination. A small amount of $\mathrm{NO}_{3}{ }^{-}$is flushed immediately after $\mathrm{N}$-fertilization; however, the $\mathrm{NO}_{3}{ }^{-}$becomes more isotopically depleted (lighter) in the succeeding months. The low $\mathrm{NO}_{3}-\mathrm{N}$ concentrations and quite depleted isotopic values suggest a source that has experienced minimal fractionation. Since leached N-fertilizer below the soybeans was slightly enriched, this lighter source of porewater $\mathrm{NO}_{3}{ }^{-}$is apparently nitrified fixed ammonia-N and/or mineralized-N from soybean roots and $\mathrm{N}$-fixation nodules.

Large amounts of $\mathrm{N}$-fertilizer are transported vertically below citrus orchards on Cheju Island. Monthly changes in the $\delta^{15} \mathrm{~N}^{-N} \mathrm{O}_{3}$ are related to the timing of periodic flushes of fertilizer-derived nitrate. Nitrate is flushed to the 1-m level within less than 1 month after fertilization and is characterized by $\delta^{15} \mathrm{~N}$ values that closely resemble those in commonly used commercial fertilizers. Leachates collected up to 3 months after fertilization are enriched several per mil. Although the majority of the fractionation is caused by volatilization, in these tropical soils of high organic-C content, denitrification is suggested to be partially responsible for the enrichment.

Commercial fertilizer leachates appear responsible for most of the groundwater contamination below the citrus growing areas; however, the slightly more enriched $\delta^{15} \mathrm{~N}$ values in the northern zone suggest that the groundwater may be impacted by proportionately greater amounts of animal-waste $\mathrm{N}$ than in the southern or western zones. On the other hand, $\mathrm{N}$ leachates from fertilized soybeans appear to have little if any impact on groundwater quality. Two municipal wells near Seogwipo City had enriched $\delta^{15} \mathrm{~N}$ values that approached or exceeded $+10 \%$ and are believed impacted by human wastes.

Acknowledgments - Funding was provided by the Korean Science and Engineering Foundation (KOSEF) through the Subtropical Horticulture Research Center at Cheju National University and by the Nebraska Research Initiative. Anita Sisco's assistance in preparing samples for N-isotope analysis and Lorraine Moon's editorial suggestions were greatly appreciated. This manuscript is ARD Journal Series No. 13047.

\section{References}

Aravena R., Evans M.L. and Cherry J.A. 1993. Stable isotopes of oxygen and nitrogen in source identification of nitrate from septic systems. Ground Wat. 31: 180-186

Bates H.K. and Spalding R.F. 1998. Aquifer denitrification as interpreted from in situ microcosm experiments. J. Environ. Qual. 27: 174-182

Berndt M.P. 1990. Sources and distribution of nitrate in groundwater at a farmed field irrigated with sewage treatment plant effluent, Tallahassee, Florida. US Geol. Surv. Water Res. Investigation Report 90-4006

Böhlke J.K. and Coplen T.B. 1995. Interlaboratory comparison of reference materials for nitrogen-isotope-ratio measurements. pp 51-66. In: Proc. of Consultants Meeting, Vienna. IAEATECDOC- 825

Böhlke J.K. and Denver J.M. 1995. Combined use of groundwater dating, chemical and isotopic analyses to resolve the history and the fate of nitrate contamination in two agricultural watersheds, Atlantic coastal plain, Maryland. Wat. Resour. Res. 31: 2319- 2339

Bremner J.M. and Edwards A.P. 1965. Determination and isotoperatio analysis of different forms of nitrogen in soils. I. Apparatus and procedure for distillation and determination of ammonium. Soil Sci. Soc. Am. Proc. 29: 504-507

Bremner J.M. and Keeney D.R. 1965. Steam distillation method for determination of ammonium, nitrate, and nitrite. Anal. Chim. Acta. 32: 485-495

Chien S., Shearer H.G. and Kohl D.H. 1977. The nitrogen isotope effect associated with nitrate and nitrite loss from waterlogged soils. Soil Sci. Soc. Am. J. 41: 63-69

Cline J.D. 1973. Denitrification and isotopic fractionation in two contrasting marine environments: the eastern tropical North Pacific Ocean and the Cariaco Trench. Ph.D. Thesis, University of California, Los Angeles

Exner M.E. and Spalding R.F. 1994. N-15 identification of nonpoint sources of nitrate contamination beneath cropland in the Nebraska Panhandle: Two case studies. Appl. Geochem. 9: 73-81

Federal Register 1975. National Interim Primary Drinking Water Standards. 40: 59566-59588

Gormly J.R. and Spalding R.F. 1979. Sources and concentrations of nitrate-nitrogen in ground water of the central Platte region, Nebraska. Ground Water 17: 291-301

Green A.R., Feast N.A., Hiscock K.M. and Dennis P.F. 1998. Identification of the source and fate of nitrate contamination of Jersey bedrock aquifer using stable isotopes of nitrogen. In: Robbins N.S. (ed.), Groundwater pollution, aquifer recharge and vulnerability, The Geological Society, London, UK

Hyun S. 1996. Direction of sustainable agriculture for environmental preservation in Cheju Island. In: The International 
Symposium for Sustainable Agriculture, pp. 117-139. Subtropical Horticulture Research Center, Chejdo, Korea

Igbal M.Z., Krothe N.C. and Spalding R.F. 1997. Nitrogen isotope indicators of seasonal variability to ground water. Environ. Geol. 32: 210-218

Junk G. and Svec H.J. 1958. The absolute abundance of the nitrogen isotopes in the atmosphere and compressed gas from various sources. Geochim. Cosmochim. Acta. 14: 234-243

Kim S.H., Song Y.C., Ko Y.G. and U Z.K. 1996. Groundwater quality characteristics on Cheju Island. In: The International Symposium for Sustainable Agriculture, pp. 83-116. Subtropical Horticulture Research Center, Chejdo, Korea

Komor S.C. and Anderson H.W. Jr. 1993. Nitrogen isotopes as indicators of nitrate sources in the Minnesota sand-plain aquifers. Ground Wat. 31: 260-270

Korom S.F. 1992. Natural denitrification in the saturated zone: A review. Wat. Resour. Res. 28: 1657-1668

Kumazawa K. 1996. Nitrate pollution in groundwater of Japan. In: The International Symposium for Sustainable Agriculture, pp. 83-116. Subtropical Horticulture Research Center, Chejdo, Korea

Kreitler C.W. 1975. Determining the source of nitrate in groundwater by nitrogen isotope studies. Rept. Univ. Texas Bur. Econ. Geol. 83, Austin

Létolle R. 1980. Nitrogen-15 in the natural environment. In: Fritz P. \& Fontes J.Ch. (eds.), Handbook of Environmental Isotope Geochemistry, pp. 407-429. Elsevier, Amsterdam, The Netherlands

Mariotti A., Landreau A. and Simon B. $1988 .{ }^{15} \mathrm{~N}$ isotope biogeochemistry and natural denitrification process in groundwater: Application to the Chalk aquifer of northern France. Geochim. Cosmochim. Acta. 52: 1869-1878
Miyaka Y. and Wada E. 1967. The abundance ratio of ${ }^{15} \mathrm{~N} /{ }^{14} \mathrm{~N}$ in marine environments. Records Oceanogr. Works Japan 9: $37-53$

Schepers J.S. and Mosier A.R. 1991. Accounting for nitrogen in nonequilibrium soil crop systems. In: Follett R.F., Keeney D.R. \& Cruse R.M. (eds.), Managing nitrogen for groundwater quality and farm profitability, pp. 125-128. American Society of Agronomy, Soil Science Society of America, Madison, WI

Shin C. 1996. The present condition of nitrate in groundwater in South Korea. In: The International Symposium for Sustainable Agriculture, Subtropical Horticulture Research Center, Chejdo, Korea, pp. 65-80.

Smith R.L., Howes B.L. and Duff J.H. 1991. Denitrification in nitrate-contaminated ground water: Occurrence in steep vertical geochemical gradients. Geochim. Cosmochim. Acta. 55: 1815-1825

Spalding R.F. and Exner M.E. 1993. Occurrence of nitrate in groundwater - A review. J. Environ. Qual. 22: 392-402

Spalding R.F., Exner M.E., Lindau C.W. and Eaton DW 1982. Investigation of sources of groundwater nitrate contamination in the Burbank-Wallula area of Washington, U.S.A. J. Hydrol. 58: 307-324

Spalding R.F., Exner M.E., Martin G.E. and Snow D.D. 1993. Effects of sludge disposal on groundwater nitrate concentrations. J. Hydrol. 141: 213-228

Tiedje J.M. 1994. Denitrifiers. In: Klute A., Weaver R.W., Mickelson S.H., Sparks D.L. \& Bartels J.M. (eds.), Methods of Soil Analysis, Part II. Microbiological and Biochemical Properties, pp. 245-267. American Society of Agronomy, Soil Science Society of America, Madison, WI

Varvel G.E. and Peterson T.A. 1990. Residual soil nitrogen as affected by continuous two-year and four-year crop rotation systems. Agron. J. 82: 958-968 